之曲線，曲線が曲率中心を内外に変える場合で，この ときは大小 2 車輪を同一軸に置き，レールはその 2 車 輪を互いに載せるようにくいちがわせておく４４什車 輪をスチアリングする方法で，図 73 のように水平ガ イドローラ $c$ と垂直車輪のスチアリングレバー端の駆 動装置 $\boldsymbol{d}$ とからなる.レバ一端は直線走行では I, 直 線から曲線に移る所では II，曲線走行では川に移る。

[大沢 水澄]

\section{$627.352: 621.875$}

[555] コンテナ輸送プログラム［O. Hartmann, Deutsche hebe-und Fördertechnik, 1967-2, Jg. 13, Ht. 2, S. 42 45, 図 3] Demag が姉妹会社ととも に行なったコンテナ荷役のプログラムである. Demag KM のコンテナアンローダは Rotterdam の Margiet 港に設置予定. 1 時間 30 個のコンテナが船から陸揚 げされる. ヨーロッパでの最初の施設はブレーメンの パセコのもので (Nohab が技携)， 1 時間 $25 \mathrm{t}$ ，コン テナ25個である. Demag のものは約 $37 \mathrm{t}$ 荷重に対し てで, 巻上高さはふ頭上 $25 \mathrm{~m}$, 巻上最大高さ $39 \mathrm{~m}$. ジブは水際レールから測り $34 \mathrm{~m}$ 横行できる張出しを 持つ. 陸側は $7 \mathrm{~m}$ の横行長さの張出しジブ, 走行レ ールゲージ $15 \mathrm{~m}$, 総計 $56 \mathrm{~m}$ の横行長さになる. 横 行装置はトロリに設置. これにより精度をあげ, ジブ をはねあげたときも陸上作業ができる.ワードレオナ 一ド（横行，走行，巻上げ下げ），コンテナ用ガイド アームは 4本, 横行装置中心距離 $17 \mathrm{~m}$, スプレッダ はコンテナの遥いに応じただちに取換えられる.Jün Kerath 製ストラドルキャリアは $30 \mathrm{t}$ 用, $25 \mathrm{~km} / \mathrm{h}$, 走行は 4 油圧モータをパラに使う. スプレッダの巻上 げ高さ $2.95 \mathrm{~m}$, 横に $\pm 450 \mathrm{~mm}$ 移動でき, $\pm 5^{\circ} 30^{\prime}$ 回 転できる. 巻上速度 $8 \mathrm{~m} / \mathrm{min}$, コンテナを取り $200 \mathrm{~m}$ 輸送距離の場所に置く作業時間は約 $2 \mathrm{~min}$. 走行速度 $8 \mathrm{~km} / \mathrm{h}$ (負荷時), 無段変速, 巻上高さ $5.3 \mathrm{~m}$, ホイ ールベース $7.0 \mathrm{~m}$ (特別製 $10.5 \mathrm{~m}$ ). [大沢 水澄]

\section{$681.11(494): 529.78: 531.76$}

[556]スイスの標準時計の変遷［F. Berger, Swiss Watch Jewelry J., 1967-1, Vol. 92, No. 1, p. 110 112, 図 4] 天文台の標準時計に振子時計を使って いた時代には最高の精度は日差 0.01 秒すなわち $10^{7}$ であった. 1948年にニューシャテル天文台で水晶時計 が採用されまむなく各国の天文台でも用いられるよう 沈った. 水晶時計の採用によって地球の回転の変動 が観測できるようになり，この研究はさらに原子時計 に引継がれている. 1952年スイス時計研究所に周波数 標準センターが設けられメーザの研究が始められた。

1964年この研究所の指導によってエボシュ社で原子時

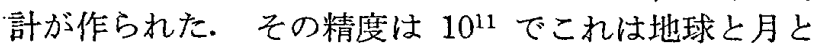
の距離を $4 \mathrm{~mm}$ の精度で測ることに相当する.

この原子時計の 2 号機が 1967 年のモントリオール 万国博に出品される. この万国博ではスイス時計工業 の名声にふさわしい役割を演じタイムセンターを受持 つ. 1966年の天文台コンクールに出品された水晶時計 をはじめ各種の時計が出品される(この記事の原文表 題の值訳は「スイスは 1967 年万国博で時刻を与える」 である).

[神保 泰雄]

\section{$681.11: 529.78: 531.76$}

[557] 高振唓数時計 [L. Defossez, Swiss Watch Jewelry J., 1967-1, Vol. 92, No. 1, p. 106 109, 表 3] 時計のテンプは毎秒 5〜6 振動 $(2.5 \sim 3 \mathrm{c} / \mathrm{s})$ のものが古くから用いられているが，最近 10 振動の ものが作られるようになった. テンプの振動数を上げ ると精度向上が期待できるということはかなり前から 言われてきたが，それに付随する困難が解決されなか ったのである．困難の第一はテンプのエネルギ消費が 増加することで，従来の炭素鋼のぜんまいの代わりに もっと大きなエネルギをたくわえ得る特殊合金ぜんま いを開発することによって解決した．第二は脱進機の 運動の高速化に伴うもので, このための新しい形状寸 法が開発された。第三は高速，高エネルギに伴う摩耗 潤滑で二硫化モリブデンの採用により解決された. こ れらの研究は引続き行なわれておりさらによい物が得 られることが期待される.

このようにして作られた 10 振動時計の精度は予想 どおりすばらしく，特に静止時と携帯時の歩度の違い が著しく改善された.

[神保 泰雄]

\section{$681.2-27$}

[558] 計器用ばね [W.R. Johnson, Instr. Contr. Systems, 1966-9, Vol. 39, No. 9, p. 123〜126, 図 5, 表 2]計器用ばねを設計使用する際に参考となるこ とを目的として，ばね特性とばね定数の選択法，ばね 特性の線形性と精度の調整法, 基準点の移動, 温度変 化に対するばね定数の安定性, ヒステリシス, 腐食さ れやすい条件での設計法, 電気伝導度, 磁気的性質, ばね特性試験機の特性にもとづく誤差と特殊精密ばね を試験するための装置などについて検討を加えた。特 別に製作された精度 $0.03 \%$ の精密試験機を使用して 测定した結果，ばねのヒステリシスは従来考えられて いたよりも，かなり小さいものであることがわかっ た.またねじりバーとつるまきねじりばねとして，七 ステリシス $0.03 \%$ 以内, 将社特性の直線性がー70〜 $270^{\circ} \mathrm{F}$ で $0.1 \%$ 以下，最大ふれを生ぜしめた状態で 72 時間, $270^{\circ}$ でクリープを全くみとめないなどの性 能のものが得られることが新しい検定装置で確認でき た.ばねの設計・使用者はばねの実際の製作法とその 過程について，製作者は製作されたばねがいかなる条 件でどのように用いられるかについて，互いに考慮す ることが特殊性能の精密計器用ばねを得るために特に 必要であると結論している. [山本孷]

\subsection{7 .6}

[559] 記録紙の選択法 [F.C. Carnes, ISA J., 1966-12, Vol. 13, No. 12, p. 55〜58, 図 5] 一般 に記録は紙にかかれる，したがって記録の精度を考え るとき，紙そのものも問題となる，記録紙選抧のある 基準がここに紹介されている．紙は湿度 $25 ７ 5 \%$ 変 化に対して $1 \%$ の寸法誤差を生ずる。むしこれを $1 \%$ 以下におさえたければポリエステルフィルムを用いる のも一つの方法である.ただしこれにむインキのの りフフィムのねじれな゙問題はある。記録の読取り やすさ，複写のしやすさ，インキののりなど記録紙と してのすべての特性を満足する紙はない。記録速度が 速いと密度の大きい，表面のスムーズなといら矛盾す る性質が記録紙に要求される。このような場合は紙も 